\title{
Molecular and Structural Basis for Sugar Recognition by Mannose 6-Phosphate Receptor Homology Domain-Containing Lectins and Proteins
}

\author{
マンノース 6 リン酸受容体相同ドメインを有するレクチンおよびタンパク質による \\ 糖鎖認識の分子構造基盤
}

\author{
Satoh, Tadashi \\ Graduate School of Pharmaceutical Sciences, Nagoya City University, 3-1 Tanabe-dori, \\ Mizuho-ku, Nagoya 467-8603, Japan \\ FAX: 81-52-836-3450, E-mail: tadashisatoh@phar.nagoya-cu.ac.jp
}

(Received on July 11, 2012, accepted on August 2, 2012)

Key Words: intracellular lectin, quality control, $N$-glycan processing, secretory pathway, mannose 6-phosphate receptor homology domain

\begin{abstract}
$N$-Linked glycans play important roles in the determination of glycoprotein fates in cells through interactions with a variety of intracellular lectins. Most of the intracellular lectins possess carbohydrate recognition domain, which is homologous to legume lectins or mannose 6-phosphate receptors (MPRs). These lectins are categorized as L-type or P-type lectins. Besides L-type lectins, recently accumulated frontal affinity chromatography and glycan microarray data have demonstrated that P-type lectins and the MPR homology (MRH) domain-containing proteins have distinct sugar-binding specificity profiles. Furthermore, newly emerged three-dimensional structural data have revealed sugar recognition mechanisms at an atomic level. This review summarizes the current state of knowledge of molecular and structural basis for sugar recognition by P-type lectins and MRH domain-containing proteins that control folding, transport, and degradation of $N$-linked glycoproteins in the secretory pathway.
\end{abstract}

要 約

$N$ 型糖鎖は、様々な細胞内レクチンとの相互作用を介して、 糖タンパク質の運命を決定する重要な役割を担っている。多 くの細胞内レクチンは、マメ科レクチンもしくはマンノース 6 リン酸受容体 $(\mathrm{MPR})$ と相同な糖鎖認識ドメインを有している。 これらレクチンは $\mathrm{L}$ 型もしくは $\mathrm{P}$ 型レクチンに分類される。 最近、L 型レクチンに加えて、フロンタルアフィニティーク ロマトグラフィーおよび糖鎖マイクロアレイのデータの蓄積 により、P 型レクチンおよび MPR と相同なドメイン $(\mathrm{MRH})$ を持つタンパク質がそれぞれ異なる糖鎖結合特異性を示すこ とが明らかになってきた。さらに最近では、糖鎖認識メカニ ズムの原子レベルでの理解も進んでいる。本総説では、分泌 経路に扔いて $N$ 型糖タンパク質のフォールディング・輸送・ 分解を制御する $\mathrm{P}$ 型レクチンおよび $\mathrm{MRH}$ ドメインを有する タンパク質による糖鎖認識の分子構造基盤の知見の現状を概 説する。

A. はじめに

真核細胞の $N$ 型糖タンパク質は様々な修飾を受け、小胞 体 $(\mathrm{ER}) \cdot$ ゴルジ体を経て目的の細胞外もしくは細胞内に輸送 される $(1 、 2)$ 。糖鎖の付加は、ポリペプチド鎖が小胞体に入っ た直後に、高マンノース型糖鎖 $\left(\mathrm{Glc}_{3} \mathrm{Man}_{9} \mathrm{GlcNAc}_{2}\right)$ ( 図 1) の形 でオリゴ糖転移酵素により行われる(3)。N 型糖鎖を持ったポ リペプチド鎖は、小胞体で様々な分子シャペロンや酸化還元 酵素の介助を受け、正しい立体構造へと折り䪶まれ、ゴルジ 体へと輸送される (4-10)。高度にミスフォールドした糖タンパ ク質は小胞体から細胞質へと逆行輸送される。最終的に、有 害なミスフォールドタンパク質は、いわゆる小胞体関連分解 (ERAD) を介して、ユビキチン・プロテアソーム経路により分 


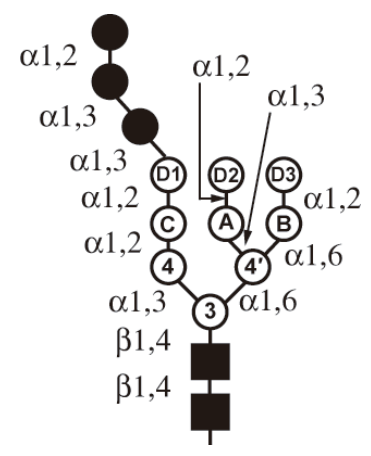

Fig. 1. Structure of $\mathrm{Glc}_{3} \mathrm{Man}_{9} \mathrm{GlcNAc}_{2}$, the common precursor of $N$-linked glycans.

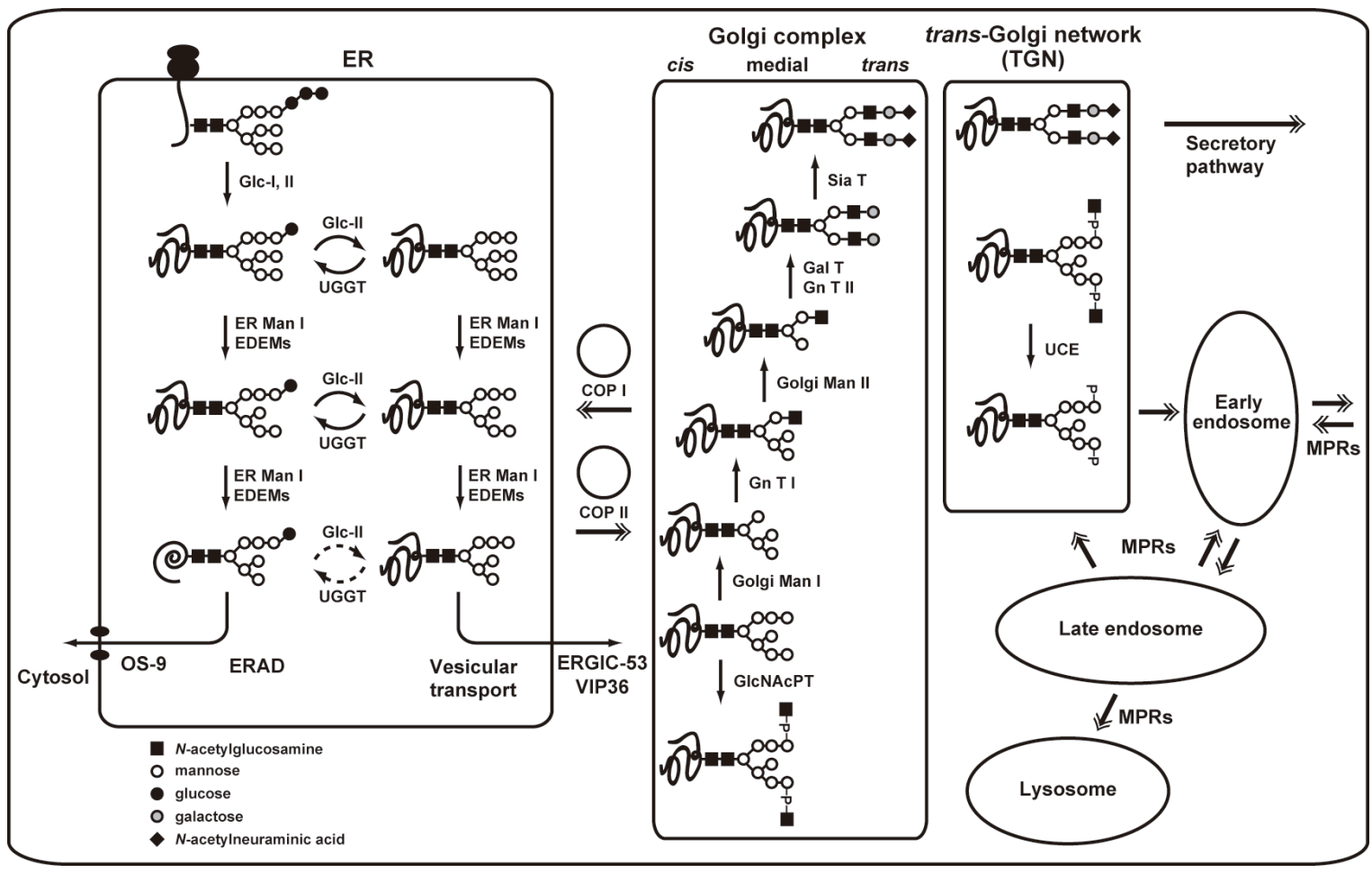

Fig. 2. Biosynthetic pathway of $\boldsymbol{N}$-linked glycoproteins. Glycosidase and glycosyltransferase involved in the oligosaccharide processing and typical intracellular lectins are shown here. Glc-I,II, glucosidase I,II; UGGT, UDPglucose:glycoprotein glycosyltransferase; ER Man I, endoplasmic reticulum mannosidase I; EDEM, ER degradation enhancing $\alpha$-mannosidase-like protein; GlcNAcPT, $N$-acetylglucosamine phosphotransferase; Golgi Man I,II, Golgi mannosidase I,II; Gn T I,II, $N$-acetylglucosaminyltransferase I,II; Gal T, galactosyltransferase; Sia T, sialyltransferase; UCE, $N$-acetylglucosamine-1phosphodiester $\alpha-N$-acetylglucosaminidase (uncovering enzyme); ERGIC-53, ER-Golgi intermediate compartment protein of $53 \mathrm{kDa}$; VIP36, vesicular integral protein of $36 \mathrm{kDa}$; OS-9, osteosarcoma amplified-9 protein; MPR, mannose 6-phospahte receptor. COP I,II, coat protein complex I,II.

proteins are degraded by ubiquitin/proteasome system via the so-called ER-associated degradation (ERAD) (11). In plants and animals, the transported glycoproteins with high-mannosetype glycan are further processed by several mannosidases and glycosyltransferases to generate a complex-type glycan in the Golgi apparatus $(1,2)$. The animal lysosomal enzymes are glycoproteins, and modified differently from the normal secretory glycoproteins by the addition of one or more mannose 6-phosphate (M6P) residues to the high-mannosetype glycan in the cis-Golgi (12-14). Subsequently, the lysosomal enzymes with M6P residues are captured by M6P
解される $(11)$ 。動植物において、ゴルジ体へ輸送された高マン ノース型糖鎖を持つ糖タンパク質は、そこで様々なマンノシ ダーゼ・糖転移酵素により更にプロセッシングされ、複合型 糖鎖が生成される $(1 、 2)$ 。動物のリソソーム酵素は糖タンパク 質であるが、通常の分泌糖タンパク質とは異なり、シスゴル ジ網で高マンノース型糖鎖に一つもしくは多数のマンノース 6 リン酸 (M6P) 残基が付加される (12-14)。その後、M6P 残基を 持つリソソーム酵素は、トランスゴルジネットワーク (TGN) で M6P 受容体 (MPR) により捕捉され、エンドソーム・リソソー 


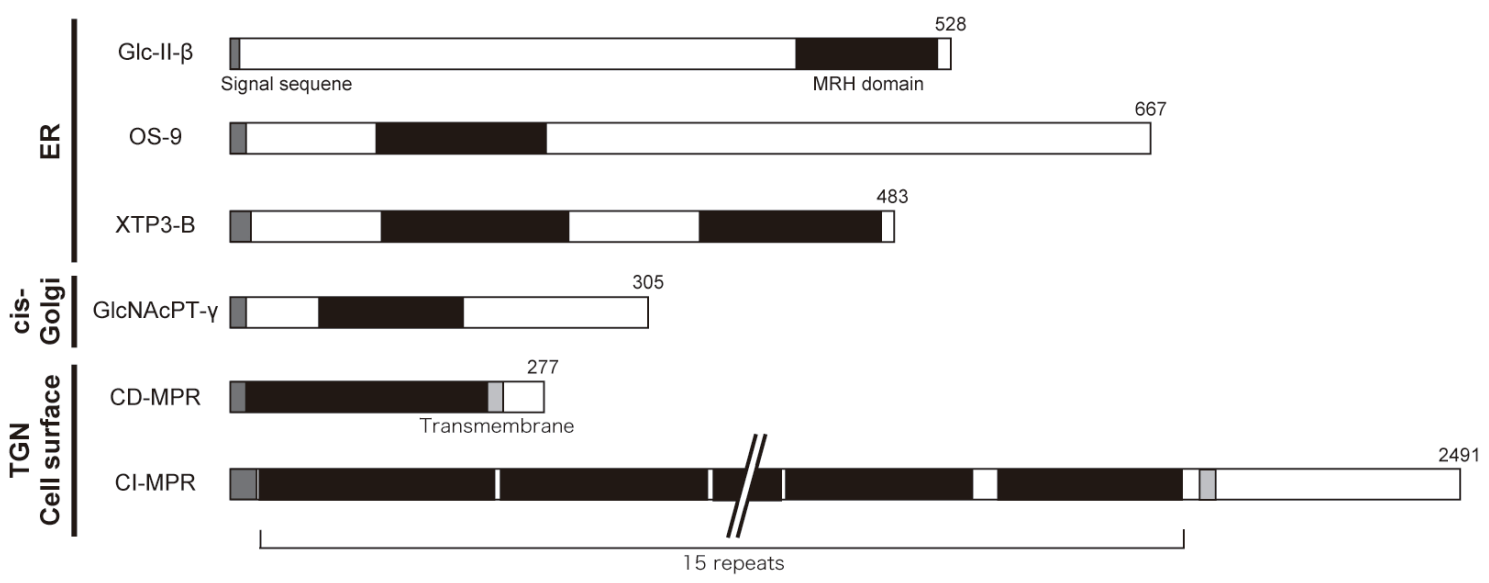

Fig. 3. MRH domain-containing lectins and proteins. The domain structure of six human MRH domain-containing lectins and proteins is presented. The MRH domain is shown in black bar, the signal sequence in dark gray bar, and the transmembrane region in light gray bar. Four and two splicing variants of human OS-9 and XTP3-B have been identified, respectively, and the longest forms are presented.

receptors (MPRs) at the trans-Golgi network (TGN) and delivered to endosomes/lysosomes.

In all these processes, $N$-glycan intermediates function as glycoprotein quality control tags, which are recognized by a series of L-type and P-type intracellular lectins (Fig. 2) (410). L-type lectins possess carbohydrate recognition domain (CRD), which is homologous to legume lectins. On the other hand, P-type lectins contain CRD, which is homologous to MPRs and thus called as MRH domain. MRH domain has also been identified in various proteins, such as glycosidase and glycosyltransferase (Fig. 3) $(12,14-16)$. This review will outline recent advances in research on the glycan-binding specificity of P-type lectins and MRH domain-containing proteins and specific interactions of MRH domains with phosphorylated and non-phosphorylated $N$-glycans.

\section{B. Role of P-Type Lectins and MRH Domain-Containing Proteins in the Secretory Pathway}

The $N$-linked oligosaccharides $\left(\mathrm{Glc}_{3} \mathrm{Man}_{9} \mathrm{GlcNAc}_{2}\right)$ tagged with nascent polypeptide chain are trimmed by several glucosidases and mannosidases in the ER (Fig. 2). Glucosidase I (Glc-I) trims outermost $\alpha 1,2$-linked glucose residue at the D1 arm immediately after the attachment of $N$-glycan $(17,18)$. Subsequently, glucosidase II (Glc-II), which contains an MRH domain in the $\beta$-subunit, removes the second and third $\alpha 1,3$-linked glucose residues $(17,19)$. UDPglucose:glycoprotein glucosyltransferase (UGGT) catalyzes re-glucosylation, thereby reproducing mono-glucosylated glycoforms (20-22). The ER chaperones calnexin and calreticulin with an L-type CRD specifically bind to the monoglucosylated $\mathrm{N}$-glycans and thereby assist the folding of the carrier proteins (23-26). This process is called "calnexin/ calreticulin cycle" (27). Elimination of the terminal glucose
ムへと輸送される。

これら全てのプロセスに扔いて、 $N$ 型糖鎖中間体は糖タン パク質の品質管理のタグとして機能し、一連の L 型および $\mathrm{P}$ 型細胞内レクチンにより認識される(図 2) (4-10)。L 型レクチ ンは、マメ科レクチンと相同な糖鎖認識ドメイン (CRD) を有 するレクチンのことを指す。一方 $\mathrm{P}$ 型レクチンとは、MRH ド メインと呼ばれる MPR と相同な CRD を有するレクチンのこ とを指す。また、MRH ドメインは、糖加水分解酵素・糖転移 酵素など、様々なタンパク質に扔いても見出されている(図 3) (12、14-16)。本総説では、P 型レクチンおよび MRH ドメイン を有するタンパク質の糖鎖結合特異性と、リン酸化抒よび非 リン酸化 $N$ 型糖鎖の相互作用に関する研究の進展について解 説する。

B. 分泌経路における $\mathrm{P}$ 型レクチンおよび $\mathrm{MRH}$ ドメインを有 するタンパク質の役割

新生ポリペプチド鎖に付加した $N$ 型糖鎖 $\left(\mathrm{Glc}_{3} \mathrm{Man}_{9} \mathrm{GlcNAc}_{2}\right)$ は、小胞体で幾つかのグルコシダーゼおよ びマンノシダーゼによってトリミングを受ける(図 2)。グルコ シダーゼI (Glc-I) は、 $N$ 型糖鎖が付加された直後に、D1 アー ム上の $\alpha 1,2$ 結合した末端のグルコース残基のトリミングを行 う (17、18)。 $\beta$ サブユニットに MRH ドメインを有するグルコ シダーゼ II (Glc-II) は、引き続き 2 番目・ 3 番目の $\alpha 1,3$ 結合し たグルコース残基を取り除く(17、19)。UDP-グルコース：糖 タンパク質グルコース転移酵素 (UGGT) は、再グルコシル化 を触媒することで、モノグルコシル化したグライコフォーム を再生させる (20-22)。L 型 CRD を持つ小胞体シャペロンであ るカルネキシンおよびカルレティキュリンは、モノグルコシ ル化された $N$ 型糖鎖と特異的に結合することを通じて、新生 ポリペプチド鎖のフォールディングの補助を行う (23-26)。こ うした一連のプロセスは、カルネキシン・カルレティキュリ 
residue in the D1 arm triggers its segregation from the ER chaperones, while the intracellular L-type lectins (ERGIC-53, VIPL, and VIP36), operating as cargo receptors, capture the exposed trimannosyl glycotope for vesicular transport (28-30). In contrast, the Man $\alpha 1,6$ glycotope exposed after trimming of mannose at the D3 arm is recognized by P-type lectin OS-9 for ERAD (31-34).

In general secretory glycoproteins, the high-mannosetype glycans are extensively trimmed by Golgi mannosidases and then subjected to $N$-acetylglucosaminylation, galactosylation, sialylation, and/or sulfation in the Golgi apparatus $(1,2)$. In marked contrast, the high-mannosetype glycans of lysosomal enzymes undergo specific modifications of M6P residues in the cis-Golgi. GlcNAcphosphotransferase (GlcNAcPT), which contains an MRH domain in the $\gamma$-subunit, is a primitive enzyme responsible for the generation of MPRs-targeted M6P-tag on $N$-linked oligosaccharides and catalyzes the attachment of GlcNAc-1phosphate to the C-6 hydroxyl group of Man residues to form the GlcNAc-P-Man phosphodiester intermediate $(35,36)$. In the second step, $N$-acetylglucosamine-1-phosphodiester $\alpha-N$ acetylglucosaminidase (also called "uncovering enzyme") removes the GlcNAc moiety in the TGN to expose M6P phosphomonoester $(37,38)$. Eventually, P-type lectins, 46$\mathrm{kDa}$ cation-dependent MPR (CD-MPR) and 300-kDa cationindependent MPR (CI-MPR), transport lysosomal enzymes from TGN to lysosomes via endosomes (12-14).

\section{Sugar-Binding Specificity of P-Type Lectins and MRH Domain-Containing Proteins}

Recently, the sugar-binding specificities of the P-type lectins and the MRH domain-containing proteins have been characterized in detail by frontal affinity chromatography (FAC) and glycan microarray analyses (Fig. 4) (31-33,39-42). The FAC data revealed that MRH domain of Glc-II $\beta$-subunit (Glc-II- $\beta$ ) recognizes the outermost $\alpha 1,2$-linked mannose (termed Man-D3) on the D3 arm (39). Similarly, enzymatic assays showed that Man-D3 residue is important for the efficient hydrolysis of glucose residues from high-mannosetype glycans by Glc-II (43-45). These results suggest that the D3 arm of high-mannose-type glycans is responsible for the regulation of the entry of glycoproteins into the calnexin/ calreticulin cycle. In marked contrast, MRH domains of ERAD lectins OS-9 and Yos9 (yeast ortholog of OS-9) recognize an exposed a1,6-linked glycotope (Man-B, Man4', and Man-3) through trimming of Man-D3 residue on the D3 arm of high-mannose-type oligosaccharides (31-33). Similarly, flow cytometry analyses of another ERAD lectin, XTP3-B, showed that the MRH domain interacts with $\mathrm{N}$-glycans containing $\alpha 1,6-$ linked glycotope (46).

MPRs are the only proteins known to bind M6P
ンサイクルと呼ばれている (27)。D1 アームの末端のマンノー スに $\alpha 1,3$ 結合したグルコースの切除は、小胞体シャペロンと の解離を引き起こす一方、小胞輸送に抢けるカーゴレセプター として機能する細胞内 L 型レクチン (ERGIC-53、VIPL および

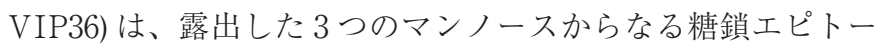
プを捕捉する (28-30)。対照的にERADに扔いては、P 型レ クチン OS-9 が、D3 アームのマンノースがトリミングを受け ることにより露出される Man 1,6 糖鎖エピトープを認識する (31-34)。

一般的な分泌糖タンパク質では、高マンノース型糖鎖はゴ ルジ体でゴルジマンノシダーゼによって刈り込まれ、その後、 GlcNAc 化、ガラクトシル化、シアリル化扮よび硫酸化修飾を 受ける (1、2)。対照的に、リソソーム酵素上の高マンノース型 糖鎖は、シスゴルジ網に扔いて M6P 残基が付加する独特の修 飾を受ける。 $\gamma$ サブユニットに MRH ドメインを持つ GlcNAc リン酸転移酵素 (GlcNAcPT) は、M6P タグの生成に関わる基 本酵素で、マンノースの C-6 水酸基に GlcNAc-1-リン酸の付 加を触媒することで、GlcNAc-P-Man リン酸ジエステル中間体 を形成させる (35、36)。2 番目のステップでは、GlcNAc-1-リン酸 ジエステル $\alpha-N$ - アセチルグルコサミニダーゼ( “脱被覆酵素” と も呼ばれる)が、TGNにおいて GlcNAc 部分を取り除き、M6P リン酸モノエステルを露出させる $(37$ 、38)。最終的に、リソ ソーム酵素は、P 型レクチンである $46 \mathrm{kDa}$ のカチオン依存性 MPR (CD-MPR) および $300 \mathrm{kDa}$ のカチオン非依存性 MPR (CIMPR)によって、TGNからエンドソームを経由してリソソー ムへと輸送される $(12-14)$ 。

\section{P 型レクチンおよび MRH ドメインを有するタンパク質の 糖鎖結合特異性}

最近、フロンタルアフィニティークロマトグラフィー (F AC) 抢よび糖鎖マイクロアレイにより、P 型レクチンおよび $\mathrm{MRH}$ ドメインを有するタンパク質の糖鎖結合特異性が詳細に 解析された (図 4) (31-33、39-42)。FAC 解析の結果、Glc-II の $\beta$ サブユニットの MRH ドメインは、D3アームの末端の $\alpha 1,2$ 結 合したマンノース (Man-D3 と呼ばれる) を認識することが明 らかにされた (39)。同様に、酵素化学的解析により Man-D3残 基は、Glc-IIによる高マンノース型糖鎖のグルコース残基の効 率的な加水分解に重要であることが明らかにされた (43-45)。 以上の結果は、D3 アーム糖鎖がカルネキシン・カルレティ キュリンサイクルの制御に関与することを示唆している。一 方、ERAD レクチンである OS-9 㧍よび Yos9 (OS-9 の酵母才 ルソログ)の MRH ドメインは、D3 アームの末端の Man-D3 残基がトリミングされることで露出する $\alpha 1,6$ 結合した糖鎖エ ピトープ (Man-B, Man-4', Man-3) を認識する(31-33)。同様に、 フローサイトメトリー解析の結果、もう一つの ERAD レクチ ンであるXTP3-B の MRH ドメインは、 $\alpha 1,6$ 糖鎖エピトープ を含む $N$ 型糖鎖と相互作用することが明らかにされた (46)。

MPR は、M6P 残基と結合することが知られている唯一 


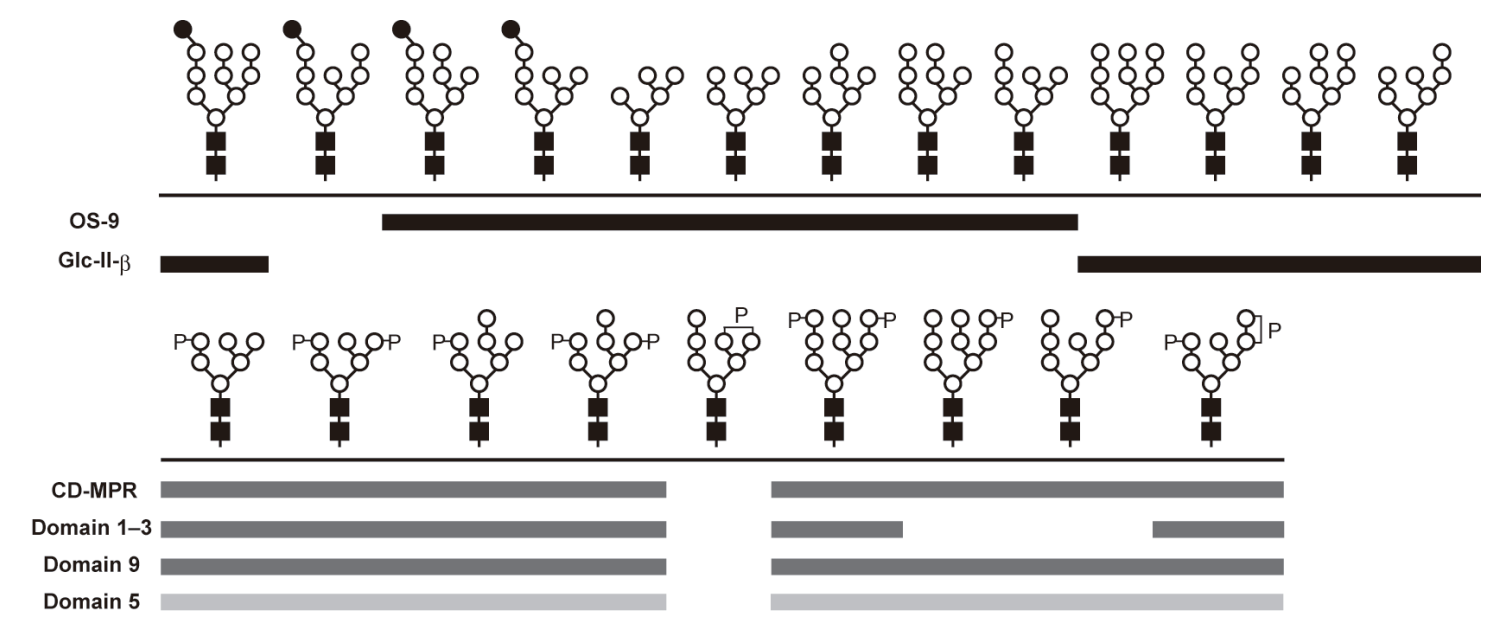

Fig. 4. Sugar-binding specificity of P-type lectins and MRH domain-containing proteins. FAC data demonstrated that MRH domains of OS-9 and Glc-II- $\beta$ have distinct sugar-binding specificities (black bar). The yeast ortholog of OS-9 (Yos9) shows the binding specificity profile similar to OS-9. Glycan microarray data showed sugar-binding specificities of MRH domains of CD-MPR and CI-MPR. CI-MPR domains 1-3 and 9 bind to M6P-containing oligosaccharides (dark gray bar), whereas domain 5 binds to GlcNAc-P-Man oligosaccharides (light gray bar).

residues. There are some notable differences between the CDand CI-MPRs, such as the number of carbohydrate binding sites and the type of phosphomannosyl residues recognized (12-14). The CD-MPR possesses one phosphomannosyl ligand-binding site per polypeptide chain, whereas the CIMPR contains three sites in domains 3,5, and 9 of the 15 homologous MRH domains. Therefore, CI-MPR is more essential than the CD-MPR for the transport of lysosomal enzymes $(47,48)$. Glycan microarray analyses have revealed that the MRH domains 3, 5, and 9 of CI-MPR have distinct sugar-binding specificity profiles (Fig. 4) (40-42). CD-MPR shows an identical sugar-binding specificity with that of CIMPR domain 9. CI-MPR domain 5 specifically binds to GlcNAc-P-Man phosphodiester intermediates but not M6P phosphomonoesters (Fig. 4, light gray bar). Unlike the CIMPR, the CD-MPR is not able to recognize GlcNAc-P-Man phosphodiester intermediates. In addition, neither receptor binds $\alpha 1,3-$ and/or $\alpha 1,6$-linked M6P residue(s) on the D2 and D3 arms (positions Man-A and Man-B), confirming the binding specificity of these MPRs for $\alpha 1,2$-linked M6P moiety. Domain 9 shows a broad range of glycan specificities, while domain 3 is unable to bind phosphorylated glycans containing a single $\alpha 1,2$-linked M6P residue on the D3 arm (position Man-D3).

\section{Three-Dimensional Structures of MRH Domains of CD- MPR, CI-MPR, and OS-9}

To date, many three-dimensional structures of MRH domains of MPRs have been determined (49-55); all showed structurally similar MRH domains with a P-type lectin fold (Fig. 5). These studies provide valuable insights into the
のタンパク質である。糖鎖認識部位の数や認識マンノースリ ン酸の種類など、CD-MPR と CI-MPR の間には、顕著な違い がある(12-14)。CD-MPR は、ポリペプチド鎖あたり一つ基質 結合部位を有しているのに対して、CI-MPR は 15 個の相同な $\mathrm{MRH}$ ドメインの中にドメイン $3 、 5 、 9$ の 3 か所の結合部位を 保持している。そのため、CI-MPR はリソソーム酵素の輸送 において、CD-MPR よりも重要である $(47 、 48) 。$ 糖鎖マイクロ アレイ解析により、CI-MPRのドメイン 3、5、9は、それぞ れ異なる糖鎖結合特異性を示すことが明らかにされた (図 4) (40-42)。CD-MPR は CI-MPR のドメイン 9 と同様の糖鎖結合 特異性を示す。CI-MPRのドメイン 5 は、M6Pリン酸モノエ ステルではなく、GlcNAc-P-Man リン酸ジエステル中間体と特 異的に結合する (図 4、薄い灰色の棒線)。一方、CD-MPR は CI-MPR とは異なり GlcNAc-P-Man リン酸ジエステル中間体 を認識することができない。さらに、どちらの受容体も D2 お よびD3アーム上の $\alpha 1,3$ および $\alpha 1,6$ 結合した M6P残基 (Man-A、 Man-B の位置) に対して結合しないことから、 $\alpha 1,2$ 結合した M6P 残基に対する MPRの結合特異性が確認された。ドメイ ン 9 は広い糖鎖結合特異性を示す一方、ドメイン 3 は 1 か所 の M6P 残基を含むリン酸化糖鎖 (D3アームの $\alpha 1,2$ 結合した Man-D3 の位置 ) には結合することはできない。

\section{CD-MPR、CI-MPR およびOS-9 のMRH ドメインの立体 構造 \\ これまでに、数多くの MPRの MRH ドメインの立体構造 が決定されている(49-55)。それらは全て、P 型レクチンフォー ルドからなる類似した MRH ドメインを有している(図 5)。以 上の研究は、本受容体によるマンノースリン酸基質の認識义}




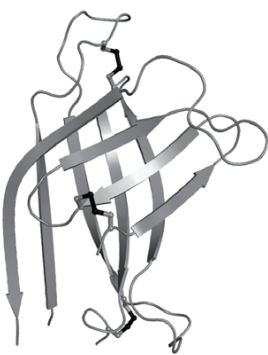

OS-9

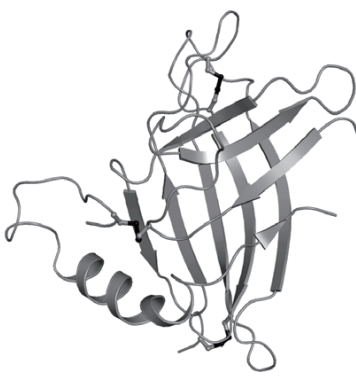

CD-MPR

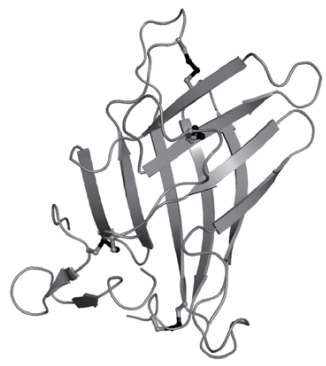

CI-MPR

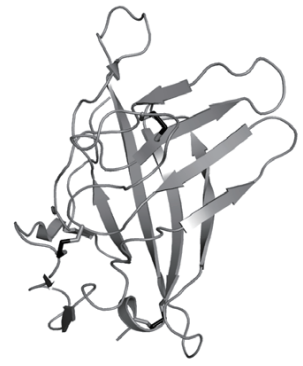

CI-MPR

Domain 5

Fig. 5. Crystal structures of MRH domains of MPRs and OS-9. The PDB codes are 1C39 (CD-MPR), 1SZ0 (CI-MPR domain 3), 2KVB (CI-MPR domain 5), and 3AIH (OS-9).

mechanisms of phosphomannosyl ligand recognition by these receptors (12-14). Crystal structures of the M6P-bound CDMP $(49,50,54)$, CI-MPR domains $1-3$ (51), and solution structure of GlcNAc-P-Man-bound domain 5 (55) revealed that four signature motif residues (Gln, Arg, Glu, and Tyr) are involved in binding of mannose moiety of M6P or GlcNAcP-Man (Fig. 6). These motif residues are present in only three (domains 3, 5, and 9) out of the $15 \mathrm{MRH}$ domains; this is consistent with the observation that only these three domains exhibit carbohydrate-binding activity. The CDMPR uses three residues (Asp, Asn, and His) to coordinate the phosphate group of M6P $(49,50,54)$, whereas domain 3 of the CI-MPR uses serine residue with an ordered water molecule (51). In CI-MPR domain 5, a characteristic tyrosine residue is responsible for GlcNAc-P-Man phosphodiester recognition (55). Although CD-MPR also has a corresponding tyrosine residue, it is unable to bind phosphodiesters possibly due to the architecture of its binding pocket. As mentioned above, CD- and CI-MPRs preferentially bind to $\alpha 1,2$-linked M6P residues, but not to $\alpha 1,3-$ and/or $\alpha 1,6$-linked M6P (40-42). This $\alpha 1,2$-linkage-specific binding seems to be achieved through a tyrosine residue that is conserved in all sugarbinding MRH domains of MPRs (Fig. 6), implying that sugarbinding specificities of MPRs are determined by the conserved tyrosine residue.

Recently reported structural data revealed that MRH domain of OS-9 interacts with Man 1 1,6Man $\alpha 1,6 \mathrm{Man}$ residues on D3 arm of high-mannose-type oligosaccharide, providing a structural basis for the sugar-binding specificity of ERAD lectins (34). The overall structure of MRH domain of OS-9 is very similar to those of MPRs (Fig. 5). The sugar-binding site of OS-9 is almost identical to the cognate M6P-binding site of MPRs (Fig. 6). As in the case of MPRs, the outer mannose (Man-B) is recognized through extensive hydrogen bonds, thus eliminating the space for the accommodation of an additional $\alpha 1,2$-linked mannose residue (Man-D3) because of a steric clash. These findings are consistent with the reports that trimming of the Man-D3 by EDEM is a critical
カニズムに関して有益な洞察をもたらした(12-14)。M6P 結合 型の CD-MPR (49、50、54) およびCI-MPR のドメイン 1-3 (51) の結晶構造、GlcNAc-P-Man 結合型のドメイン 5 (55) の溶液構 造解析の結果、四つ組モチーフ (Gln, Arg, Glu, Tyr)が M6P も しくは GlcNAc-P-Manのマンノース部分との結合に関与する ことが見出された (図 6)。これらのモチーフ残基は、15 個の $\mathrm{MRH}$ ドメインのうち 3 個 (ドメイン $3 、 5 、 9$ ) にのみ存在する。 この事実は、これら 3 つのドメインのみが糖鎖結合活性を示 すという結果と一致している。CD-MPR では、M6P のリン酸 基との結合に 3 つのアミノ酸残基 (Asp, Asn, His) が関わって いるが (49、50、54)、CI-MPR のドメイン 3 では水分子とセリン 残基が用いられている (51)。CI-MPR のドメイン 5 では、特徵 的なチロシン残基が GlcNAc-P-Man リン酸ジエステルの認識 に関わっている (55)。CD-MPR も同様のチロシン残基を有して いるが、結合ポケット構造が異なるため、リン酸ジエステルと は結合することは出来ない。上記の様に、CD-MPR およびCIMPR は $\alpha 1,3$ もしは $\alpha 1,6$ 結合した M6P 残基ではなく、 $\alpha 1,2$ 結合したものと特異的に結合する (40-42)。この $\alpha 1,2$ 結合特異 的な相互作用は、MRH ドメインの糖鎖結合部位で保存されて いるチロシン残基を介してなされていると思われる(図 6)。す なわち、MPRの糖鎖結合特異性は、この保存されたチロシン 残基によって決定されるのかもしれない。

最近報告された構造解析の結果、OS-9 の MRH ドメイン は高マンノース型糖鎖の D3 アームの Mana1,6Mana1,6Man 残 基と相互作用することが見出され、 $\mathrm{ERAD} レ$ レンの糖鎖結 合特異性の構造基盤がもたらされた (34)。OS-9 の MRH ドメ インの全体構造はMPRのものと良く類似している(図 5)。ま た、OS-9 の糖鎖結合部位は、MPR の M6P 結合部位とほほ一 致している (図 6)。MPR と同様に、末端のマンノース (Man-B) は水素結合を介して強固に認識されている。そのため、 $\alpha 1,2$ 結合したマンノース残基 (Man-D3) を導入することは立体障害 を起こしてしまい、これを収容できるスペースは存在しない。 これらの結果は、EDEM による Man-D3 残基のトリミングが、 糖タンパク質 $\mathrm{ERAD} に$ に扔いて重要であるという報告と一致し 


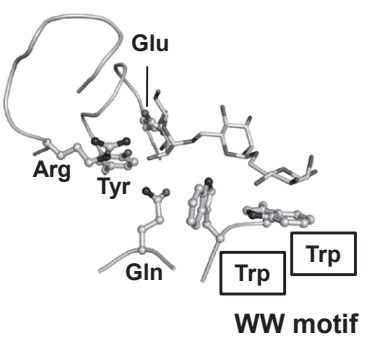

OS-9

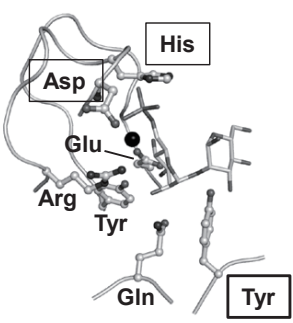

CD-MPR

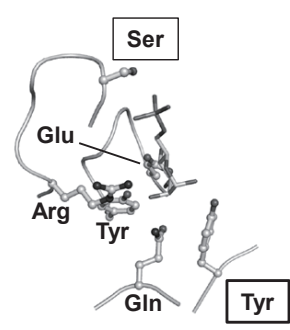

CI-MPR

Domain 3

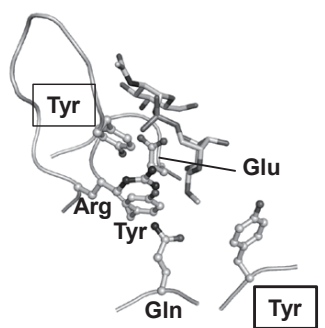

CI-MPR

Domain 5

Fig. 6. Close-up view of sugar-binding site of MRH domains. The four conserved signature motif residues (Gln, Arg, Glu, and Tyr) are shown. The phosphate-binding residues in MPRs are highlighted by boxes. Tryptophan and tyrosine residues that may determine their sugar-binding specificities are highlighted by bold boxes. Atomic coordinate of CI-MPR domain 5/ GlcNAc-P-Man docking model is kindly provided by Prof. Nancy Dahms (Medical College of Wisconsin, USA).

process for glycoprotein ERAD $(31,32,56,57)$. Although four signature motif residues (Gln, Arg, Glu, and Tyr) are highly conserved among these MRH domains, phosphatebinding residues (Asp, Asn, His, and Ser) of MPRs are not conserved in OS-9. Instead, a steric hindrance occurs if M6P residue is superimposed onto the mannose-binding site of OS9. This is consistent with previous biochemical data showing that M6P does not inhibit OS-9 ligand binding (33). Besides the canonical site, OS-9 MRH domain additionally contains unique contiguous double tryptophan residues (WW motif) for Man $\alpha 1,6$ glycotope recognition (Fig. 6). The inner $\alpha 1,6-$ linked mannose residues (Man-4' and Man-3) are recognized mainly through hydrophobic interactions with the WW motif. In distinct contrast, the WW motif is replaced with $\mathrm{Xxx}$ Tyr residues in the MPRs that recognize a1,2-linked M6P. Hence, sugar-binding specificity of OS-9 is determined by a combination of canonical sugar-binding residues and the characteristic WW motif.

\section{E. Insights into Sugar-Binding Mode of Other MRH Domain-Containing Lectins and Proteins}

Structure-based sequence alignment analysis of GlcII- $\beta$ and XTP3-B MRH domains showed that cysteine and hydrophobic residues that are involved in the formation of disulfide bridges and $\beta$-barrel are highly conserved in these domains, suggesting that the MRH domains have a similar P-type lectin fold (34). Furthermore, four signature motif residues (Gln, Arg, Glu, and Tyr) involved in mannose binding in the MPRs and OS-9 are completely conserved in the MRH domains, suggesting that mannose-binding mode at the primary binding site is essentially the same among the MRH domains.

It has been suggested that lectin XTP3-B recognizes $\alpha 1,6$-linked mannobiose or mannotriose structures on the D3 arm through the C-terminal MRH domain (46). XTP3-B has two MRH domains, $\mathrm{N}$-terminal domain 1 and $\mathrm{C}$-terminal
ている(31、32、56、57)。四つ組モチーフ (Gln, Arg, Glu, Tyr) は $\mathrm{MRH}$ ドメイン間で高度に保存されているが、MPRのリン酸 結合残基 (Asp, Asn, His, Ser) は OS-9 では保存されていない。 それどころか、OS-9 のマンノース結合部位に M6P 残基を重 ね合わせた場合、立体障害が生じてしまう。これは、M6P が OS-9 の基質結合を阻害しないという以前の生化学データと一 致している (33)。OS-9 の MRH ドメインは、典型的な結合部 位に加えて、 $\alpha 1,6$ 糖鎖エピトープ認識に重要な特徵的な 2 つ の連続したトリプトファン残基 ( $\mathrm{WW}$ モチーフ)を有している ( 図 6)。WW モチーフは、内側の $\alpha 1,6$ 結合したマンノース残 基(Man-4'㧍よびMan-3) を、疎水性相互作用を介して認識する。 これに反して、 $\alpha 1,2$ 結合した M6P を特異的に認識する MPR では、WW モチーフは Xxx-Tyr 残基に置換されている。した がって、OS-9 の糖鎖結合特異性は、典型的な糖鎖結合残基と 特徵的な WW モチーフの連携により決定されているといえる。

E. 他の MRH ドメインを有するレクチンおよびタンパク質の 糖鎖結合様式の見解

Glc-II- $\beta$ 抢よびXTP3-B の MRH ドメインの構造に基づい た配列解析により、ジスルフィド結合掞よび $\beta$ バレルの形成 に関与するシステインおよび疎水性残基がドメイン間で高度 に保存されていることが明らかにされた (34)。これにより、こ れらの MRH ドメインが同様の P 型レクチンフォールドを有 していることが推測された。さらに、MPR と OS-9 のマンノー 又結合に関わる四つ組モチーフ (Gln, Arg, Glu, Tyr) は MRH ドメイン間で完全に保存されて扮り、マンノース結合様式は 本質的に一致していることが示唆された。

レクチン XTP3-B は、C 末端 MRH ドメインを介して D3 アームの $\alpha 1,6$ 結合したマンノース 2 糖・3 糖構造を認識する ことが示唆されている(46)。XTP3-B はN 末端側にドメイン 1、C 末端側にドメイン 2 を有している。WW モチーフなど、 C 末端ドメイン 2 は OS-9 と高い配列保存性を有することから、 


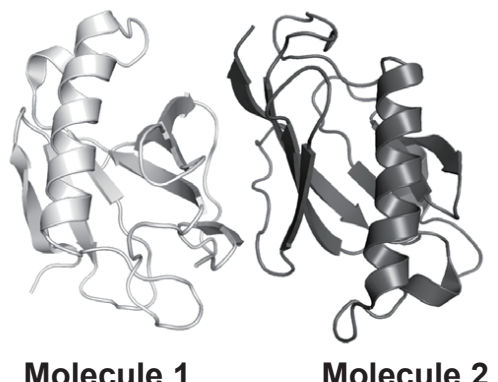

Molecule 1
Molecule 2
Fig. 7. Crystal structures of dimerization domain of Yos9 (PDB code: 2YMA). Molecules 1 and 2 are colored white and gray, respectively. domain 2. The sequence conservation of the C-terminal domain 2 with OS-9, including the WW motif, suggests that the sugar-binding mode of this domain is essentially identical with that of the OS-9 MRH domain. Currently, there is no conclusive explanation for the lack of interaction of the domain 1 with sugar ligands, because the important sequences of this domain, such as four signature motif residues (Gln, Arg, Glu, and Tyr), are highly conserved. To explain this enigma, determination of three-dimensional structure and detailed sugar-binding specificity profiles of the XTP3-B MRH domains will be necessary.

Intriguingly, Glc-II- $\beta$ MRH domain exhibits opposite specificities. Unlike ERAD lectins, the MRH domain has higher affinity for $\alpha 1,2$-linked mannobiose structure on the D3 arm (39). The MRH domain of Glc-II- $\beta$ does not possess a WW motif, but instead has a tyrosine residue conserved among MPRs $(49-51,54,55)$. Like Glc-II- $\beta$, GlcNAcPT also has the corresponding tyrosine residue in the MRH domain and shows a similar substrate specificity for $\alpha 1,2$-linked mannosyl ligands (35). The sequence conservation suggests that these MRH domains bind the $\alpha 1,2$-linked mannose residues of high-mannose-type glycans in a manner similar to MPRs. Additional biochemical and structural studies will be necessary to understand the mechanisms underlying the linkage-specific sugar recognition by the MRH domains.

\section{F. Perspective}

Structural biology studies in conjunction with FAC and glycan microarray approaches have revealed the molecular and structural basis for sugar recognition by P-type lectins and MRH domain-containing proteins that are involved in the folding, transport, and degradation of glycoproteins. One of the remaining important issues is the understanding of mechanisms underlying folding state judgment in the ER quality control system. Although direct sensing of folding states has been suggested in some reports $(26,58,59)$, intracellular lectins appear to employ molecular chaperones for the recognition of misfolded glycoproteins in many cases $(15,16,27,60-62)$. Besides molecular chaperones, protein disulfide isomerase (PDI)-like oxidoreductases and other folding assistants make complexes with these intracellular
このドメインの糖鎖認識様式は OS-9 のものと本質的に一致し ていることが示唆される。四つ組モチーフ (Gln, Arg, Glu, Tyr) など、このドメインの重要な配列は高度に保存されているた め、今のところ、ドメイン 1 が糖鎖リガンドと結合しない決 定的な理由は得られていない。この謎を解き明かすためには、 XTP3-B の MRH ドメインの立体構造の決定、および詳細な糖 鎖結合特異性のプロファイリングが必要となるだろう。

興味深いことに、Glc-II- $\beta$ の MRH ドメインは、ERAD レ クチンと真逆の結合特異性を示す。すなわち、ERADレク チンと異なり、D 3 アームの $\alpha 1,2$ 結合したマンノース 2 糖構 造に対して高い親和性を示す (39)。Glc-II- $\beta$ の MRH ドメイン はWWモチーフを持たず、代わりにMPRの間で保存され たチロシン残基を有している (49-51、54、55)。Glc-II- $\beta$ と同様 に、GlcNAcPT はチロシン残基を MRH ドメインに持ち、 $\alpha 1,2$ 結合したマンノース基質に対して良く似た基質特異性を示す (35)。この配列保存は、これらの MRH ドメインが MPR と同 様の相互作用様式で、高マンノース型糖鎖の $\alpha 1,2$ 結合したマ ンノース残基に結合することを意味しているのかもしれない。 $\mathrm{MRH}$ ドメインを介した結合特異的な糖鎖認識に関するメカニ ズムの理解には、更なる生化学的・構造的研究が必要となる だろう。

F.おわりに

FAC および糖鎖マイクロアレイと連動した構造生物学 研究は、糖タンパク質のフォールディング・輸送・分解に関 わる $\mathrm{P}$ 型レクチンおよび $\mathrm{MRH}$ ドメインを有するタンパク 質による糖鎖認識の分子構造基盤を明らかにしてきた。依然 として残る重要な課題の一つは、小胞体品質管理機構におけ るフォールディング状態の審判を下すメカニズムの解明であ る。幾つかの論文で、直接細胞内レクチンがフォールディン

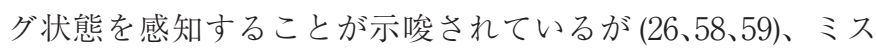
フォールド糖タンパク質の認識において、多くの場合は、分 子シャペロンを利用していると思われる $(15 、 16 、 27 、 60-62) 。 さ$ らに分子シャペロンに加えて、細胞内レクチンはタンパク質 ジスルフィド異性化酵素 (PDI) 様の酸化還元酵素やその他の フォールディング補助因子と複合体を形成する (63-65)。ごく 最近、Yos9 の MRH ドメインに隣接する C 末端ドメインの結 
lectins (63-65). Very recently, crystal structure of C-terminal domain of Yos9 adjacent to the MRH domain has been reported (Fig. 7) (66). This study provided structural insights into a dimeric state of the membrane-embedded ERAD machinery in the luminal side. Further biochemical and biophysical studies on intracellular lectins together with their cognate partners will provide new mechanistic insights into the glycoprotein folding surveillance system.

\section{Acknowledgements}

I would like to express my gratitude to my former mentor, Dr. Yoshiki Yamaguchi (RIKEN-ASI), for his support of my research. The structural study of OS-9 was performed in his laboratory. I would also like to thank Prof. Koichi Kato (National Institutes of Natural Sciences) and Dr. Yukiko Kamiya (Nagoya Univ.) for their helpful comments and Prof. Nancy Dahms (Medical College of Wisconsin, USA) for providing the atomic coordinate of the threedimensional structural model for binding between CI-MPR domain 5 and GlcNAc-P-Man phosphodiester (Fig. 6). I received financial support from Global COE program (Frontier Biomedical Science Underlying Organelle Network Biology, Osaka University) for young scientists and by Grant-in-Aid for Science Research (22020037, 23121532 and 24770102) from the Ministry of Education, Culture, Sports, Science and Technology of Japan are acknowledged.
晶構造が報告された(図 7) (66)。この研究は、膜に埋め込まれ たERAD 装置の小胞体内腔における二量体状態に関する構造 的知見をもたらした。今後、細胞内レクチンとそのパートナー 分子の更なる生化学および生物物理学的研究を介して、糖夕 ンパク質フォールディング監視システムに関する新たな知見 がもたらされることが期待される。

謝辞

前所属の指導者として私の研究を支えて下さいました山 口芳樹先生 ( 理研・基幹研 ) に深く感謝申し上げます。OS-9 の 構造研究は山口先生の研究で行われたものです。加藤晃一先 生 (自然科学研究機構)、神谷由紀子博士 (名古屋大学) には 多くのご助言を頂きました。図 6 の CI-MPR のドメイン 5 と GlcNAc-P-Man リン酸ジエステルの複合体のモデル 3 次元構造 は、Nancy Dahms 教授 (米国ウィスコンシン医科大学)のご 厚意によるものです。大阪大学グローバル COE プログラム・ オルガネラネットワーク医学創成プログラムならびに文部科 学省科学研究費補助金による支援に感謝いたします。

\section{References}

1. Kornfeld, R., and Kornfeld, S. (1985) Annu. Rev. Biochem. 54, 631-664.

2. Betenbaugh, M. J., Tomiya, N., Narang, S., Hsu, J. T., and Lee, Y. C. (2004) Curr. Opin. Struct. Biol. 14, $601-606$.

3. Kelleher, D. J., and Gilmore, R. (2006) Glycobiology 16, 47R-62R.

4. Ellgaard, L., and Helenius, A. (2003) Nat. Rev. Mol. Cell. Biol. 4, 181-191.

5. Kato, K., and Kamiya, Y. (2007) Glycobiology 17, 1031-1044.

6. Takeda, Y., Totani, K., Matsuo, I., and Ito, Y. (2009) Curr. Opin. Chem. Biol. 13, 582-591.

7. Lederkremer, G. Z. (2009) Curr. Opin. Struct. Biol. 19, 515-523.

8. Aebi, M., Bernasconi, R., Clerc, S., and Molinari, M. (2010) Trends Biochem. Sci. 35, 74-82.

9. Kamiya, Y., Satoh, T., and Kato, K. (2012) Biochim. Biophys. Acta 1820, 1327-1337.

10. Kamiya, Y., and Kato, K. (2006) Trends Glycosci. Glycotechnol. 18, 231-244.

11. McCracken, A. A., and Brodsky, J. L. (1996) J. Cell. Biol. 132, 291-298.

12. Dahms, N. M., Olson, L. J., and Kim, J. J. (2008) Glycobiology 18, 664-678.

13. Kim, J. J., Olson, L. J., and Dahms, N. M. (2009) Curr. Opin. Struct. Biol. 19, 534-542.

14. Castonguay, A. C., Olson, L. J., and Dahms, N. M. (2011) Biochim. Biophys. Acta 1810, 815-826.

15. Hosokawa, N., Kamiya, Y., and Kato, K. (2010) Glycobiology 20, 651-660.

16. Hosokawa, N., Kato, K., and Kamiya, Y. (2010) Meth. Enzymol. 480, 181-197.

17. Grinna, L. S., and Robbins, P. W. (1980) J. Biol. Chem. 255, 2255-2258.

18. Deprez, P., Gautschi, M., and Helenius, A. (2005) Mol. Cell 19, 183-195.

19. Totani, K., Ihara, Y., Matsuo, I., and Ito, Y. (2006) J. Biol. Chem. 281, 31502-31508.

20. Taylor, S. C., Ferguson, A. D., Bergeron, J. J., and Thomas, D. Y. (2004) Nat. Struct. Mol. Biol. 11, $128-134$.

21. Totani, K., Ihara, Y., Tsujimoto, T., Matsuo, I., and Ito, Y. (2009) Biochemistry 48, 2933-2940.

22. D’Alessio, C., Caramelo, J. J., and Parodi, A. J. (2010) Semin. Cell. Dev. Biol. 21, 491-499.

23. Schrag, J. D., Bergeron, J. J., Li, Y., Borisova, S., Hahn, M., Thomas, D. Y., and Cygler, M. (2001) Mol. Cell 8, $633-644$.

24. Caramelo, J. J., and Parodi, A. J. (2008) J. Biol. Chem. 283, 10221-10225.

25. Kozlov, G., Pocanschi, C. L., Rosenauer, A., Bastos-Aristizabal, S., Gorelik, A., Williams, D. B., and Gehring, K. (2010) J. Biol. Chem. 285, 38612-38620.

26. Chouquet, A., Païdassi, H., Ling, W. L., Frachet, P., Houen, G., Arland, G. J., and Gaboriaud, F. (2011) PLoS ONE 6, e17886.

27. Williams, D. B. (2006) J. Cell. Sci.119, 615-623.

28. Kamiya, Y., Yamaguchi, Y., Takahashi, N., Arata, Y., Kasai, K. I., Ihara, Y., Matsuo, I., Ito, Y., Yamamoto, K., and Kato, K. (2005) J. Biol. Chem. 280, 37178-37182.

29. Kamiya, Y., Kamiya, D., Yamamoto, K., Nyfeler, B., Hauri, H. P., and Kato, K. (2008) J. Biol. Chem. 283, $1857-1861$. 
30. Satoh, T., Cowieson, N. P., Hakamata, W., Ideo, H., Fukushima, K., Kurihara, M., Kato, R., Yamashita, K., and Wakatsuki, S. (2007) J. Biol. Chem. 282, 28246-28255.

31. Quan, E. M., Kamiya, Y., Kamiya, D., Denic, V., Weibezahn, J., Kato, K., and Weissman, J. S. (2008) Mol. Cell 32, $870-877$.

32. Hosokawa, N., Kamiya, Y., Kamiya, D., Kato, K., and Nagata, K. (2009) J. Biol. Chem. 284, 17061-17068.

33. Mikami, K., Yamaguchi, D., Tateno, H., Hu, D., Qin, S. Y., Kawasaki, N., Yamada, M., Matsumoto, N., Hirabayashi, J., Ito, Y., and Yamamoto, K. (2010) Glycobiology 20, 310-321.

34. Satoh, T., Chen, Y., Hu, D., Hanashima, S., Yamamoto, K., and Yamaguchi, Y. (2010) Mol. Cell 40, $905-916$.

35. Kudo, M., and Canfield, W. M. (2006) J. Biol. Chem. 281, 11761-11768.

36. Qian, Y., Lee, I., Lee, W. S., Qian, M., Kudo, M., Canfield, W. M., Lobel, P., and Kornfeld, S. (2010) J. Biol. Chem. $285,3360-3370$.

37. Rohrer, J., and Kornfeld, R. (2001) Mol. Biol. Cell 12, 1623-1631.

38. Kornfeld, R., Bao, M., Brewer, K., Noll, C., and Canfield, W. (1999) J. Biol. Chem. 274, 32778-32785.

39. Hu, D., Kamiya, Y., Totani, K., Kamiya, D., Kawasaki, N., Yamaguchi, D., Matsuo, I., Matsumoto, N., Ito, Y., Kato, K., and Yamamoto, K. (2009) Glycobiology 19, 1127-1135.

40. Song, X., Lasanajak, Y., Olson, L. J., Boonen, M., Dahms, N. M., Kornfeld, S., Cummings, R. D., and Smith, D. F. (2009) J. Biol. Chem. 284, 35201-35214.

41. Bohnsack, R. N., Song, X., Olson, L. J., Kudo, M., Gotschall, R. R., Canfield, W. M., Cummings, R. D., Smith, D. F., and Dahms, N. M. (2009) J. Biol. Chem. 284, 35215-35226.

42. Castonguay, A. C., Lasanajak, Y., Song, X., Olson, L. J., Cummings, R. D., Smith, D. F., and Dahms, N. M. (2012) Glycobiology 22, 983-996.

43. Watanabe, T., Totani, K., Matsuo, I., Maruyama, J., Kitamoto, K., and Ito, Y. (2009) Glycobiology 19, 834-840.

44. Stigliano, I. D., Caramelo, J. J., Labriola, C. A., Parodi, A. J., and D’Alessio, C. (2009) Mol. Biol. Cell 20, $3974-3984$.

45. Stigliano, I. D., Alculumbre, S. G., Labriola, C. A., Parodi, A. J., and D’Alessio, C. (2011) Mol. Biol. Cell 22, $1810-1823$.

46. Yamaguchi, D., Hu, D., Matsumoto, N., and Yamamoto, K. (2010) Glycobiology 20, 348-355.

47. Pohlmann, R., Boeker, M. W., and von Figura, K. (1995) J. Biol. Chem. 270, 27311-27318.

48. Ludwig, T., Munier-Lehmann, H., Bauer, U., Hollinshead, M., Ovitt, C., Lobel, P., and Hoflack, B. (1994) EMBO J. 13 , $3430-3437$.

49. Roberts, D. L., Weix, D. J., Dahms, N. M., and Kim, J. J. (1998) Cell 93, 639-648.

50. Olson, L. J., Zhang, J., Lee, Y. C., Dahms, N. M., and Kim, J. J. (1999) J. Biol. Chem. 274, 29889-29896.

51. Olson, L. J., Dahms, N. M., and Kim, J. J. (2004) J. Biol. Chem. 279, 34000-34009.

52. Olson, L. J., Yammani, R. D., Dahms, N. M., and Kim, J. J. (2004) EMBO J. 23, 2019-2028.

53. Brown, J., Esnouf, R. M., Jones, M. A., Linnell, J., Harlos, K., Hassan, A. B., and Jones, E. Y. (2002) EMBO J. $21,1054-1062$.

54. Olson, L. J., Hindsgaul, O., Dahms, N. M., and Kim, J. J. (2008) J. Biol. Chem. 283, 10124-10134.

55. Olson, L. J., Peterson, F. C., Castonguay, A., Bohnsack, R. N., Kudo, M., Gotschall, R. R., Canfield, W. M., Volkman, B. F., and Dahms, N. M. (2010) Proc. Natl. Acad.Sci. U.S. A. 107, 12493-12498.

56. Hosokawa, N., Tremblay, L. O., Sleno, B., Kamiya, Y., Wada, I., Nagata, K., Kato, K., and Herscovics, A. (2010) Glycobiology 20, 567575.

57. Clerc, S., Hirsch, C., Oggier, D. M., Deprez, P., Jakob, C., Sommer, T., and Aebi, M. (2009) J. Cell. Biol. 184, $159-172$.

58. Yamaguchi, Y., Hirao, T., Sakata, E., Kamiya, Y., Kurimoto, E., Yoshida, Y., Suzuki, T., Tanaka, K., and Kato, K. (2007) Biochem. Biophys. Res. Commun. 362, 712-716.

59. Appenzeller-Herzog, C., Nyfeler, B., Burkhard, P., Santamaria, I., Lopez-Otin, C., and Hauri, H. P. (2005) Mol. Biol. Cell 16, $1258-1267$.

60. Carvalho, P., Goder, V., and Rapoport, T. A. (2006) Cell 126, 361-373.

61. Denic, V., Quan, E. M., and Weissman, J. S. (2006) Cell 126, 349-359.

62. Gauss, R., Jarosch, E., Sommer, T., and Hirsch, C. (2006) Nat. Cell. Biol. 8, 849-854.

63. Frickel, E. M., Riek, R., Jelesarov, I., Helenius, A., Wuthrich, K., and Ellgaard, L. (2002) Proc. Natl. Acad. Sci. U. S. A. 99, 1954-1959.

64. Pollock, S., Kozlov, G., Pelletier, M. F., Trempe, J. F., Jansen, G., Sitnikov, D., Bergeron, J. J., Gehring, K., Ekiel, I., and Thomas, D. Y. (2004) EMBO J. 23, 1020-1029.

65. Meunier, L., Usherwood, Y. K., Chung, K. T., and Hendershot, L. M. (2002) Mol. Biol. Cell. 13, 4456-4469.

66. Hanna, J., Schutz, A., Zimmermann, F., Behlke, J., Sommer, T., and Heinemann, U. (2012) J. Biol. Chem. $287,8633-8640$.

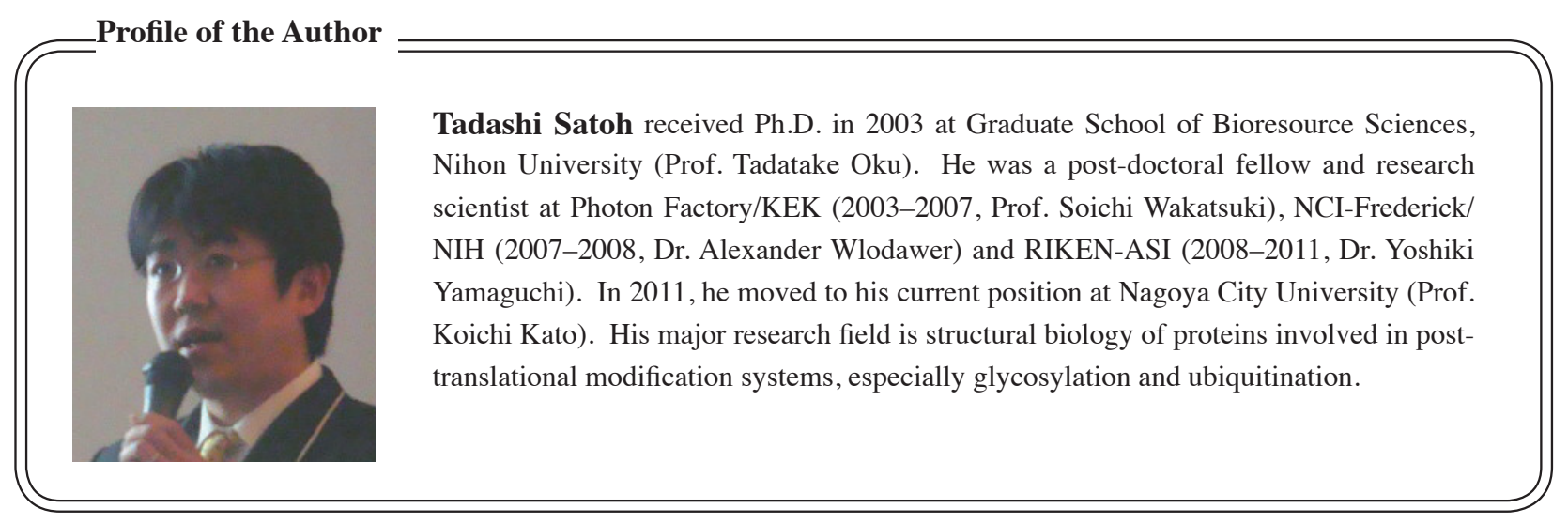

